\title{
On Trochamijiella gollesstanehi, gen. nov et sp. nov. (Foraminiferida, Loftusiacea), an index for the Middle Eastern marine Late Bathonian
}

\author{
J. ATHERSUCH \\ StrataData Litd., \\ 16 Ottershaw Park, \\ Chobham Road, Ottershaw, \\ Surrey KT16 OQG
}

\author{
F.T. BANNER \\ Department of Geological Sciences, \\ University College, \\ Gozer Street. \\ London WC1E 6BT
}

\author{
M.D. SIMMONS \\ BP Exploration, \\ Stockley Park, \\ Uxbridge, \\ UB11 1BF
}

\begin{abstract}
The new taxon Trochamijiella gollesstanehi is described; it is morphologically similar to, but phylogenetically distinct from, Amijiella, and is initially trochospiral; it is known from Iran, the United Arab Emirates and Oman, and is believed to characterise the Late Bathonian. Primary type specimens of Amijiella amiji and Haurania deserta are refigured for comparison and are believed to characterise Early Bathonian and older Jurassic strata. All three genera are reclassified and all are placed in the Biokovinidae Gušić, 1977. J.micropalaeontol. 11(1): 7-12, June, 1992.
\end{abstract}

\section{INTRODUCTION}

In the early 1960s, when micropalaeontological biostratigraphy was first being applied to the Jurassic sequences of shelf limestones being drilled off-shore of Abu-Dhabi, U.A.E., it was realised that many foraminifera, readily recognisable in thin-section and biostratigraphically valuable, were not identifiable with any known, published taxa. They were recorded by BP Exploration Co laboratory staff (including FTB) but were not formally named or described in publication. Contemporaneously, Ali Gollesstaneh was researching at University College London the micropalaeontological stratigraphy of the Jurassic-Cretaceous Khami Group of Fars Province, Iran. One of us (FTB) examined his slides with him, while his work was in progress. It was recognised that one of the Jurassic Khami Group foraminifera was the same as one of the Jurassic Araej Formation foraminifera of off-shore Abu Dhabi; it was one of those which was potentially useful stratigraphically but it had no name. In consequence, Gollesstaneh named it "Iranica slingeri" in his ensuing thesis, but it remained unpublished until Gollesstaneh's (1974) review of the KhamiGroup biostratigraphy; unfortunately, the species, although mentioned, was then undescribed, so it became nomen nudum. Following the revolution in Iran, Gollesstaneh's work in that country ceased.

In this paper, we formally describe, name and classify the taxon and indicate its biostratigraphical value as a Bathonian index in the drilled sequences of marine, shelf limestones of the Middle East.

\section{SYSTEMATIC DESCRIPTIONS}

Order Foraminiferida Eichwald, 1830

Suborder Textulariina Delage \& Hérouard, 1896

Superfamily Biokovinacea Gušić, 1977

Family Biokovinidae Gušić, 1977

Trochamijiella gen. nov.

Type species. Trochamijiella gollesstanehi sp. nov.

Derivation of name. Troch-, trochospiral, + Amijiella, genus.
Diagnosis. Test calc-agglutinating, septate, uniserial, initially trochospiral, later uncoiling and becoming rectilinear, with chambers approximately circular in section perpendicular to the long axis; in the coiled test, the aperture is initially interiomarginal and single, but it later becomes areal, multiple and cribrate; in the uncoiled, rectilinear test, the multiple, pore-like apertures are confined to the central, median part of each septum; the rectilinear chambers marginally possess vertical partitions which are arranged radially and extend inwards, from the lateral chamber walls, for about one-quarter to one-half of the chamber diameter (the apertural area of each septum overlaps with the innermost extent of many of these radial partitions); the radial, vertical partitions are usually simple and rarely bifurcate; the wall of the test is solid and is not known to become protocanaliculate or canaliculate.

Differentiation. Trochamijiella differs from both Haurania Henson and Amijiella Loeblich \& Tappan by its early trochospiral coil; in the megalospheric form, at least, Haurania deserta Henson lacks an initial coil (Pl. 2, fig. 5), while the initial coil of Amijiella amiji (Henson) is clearly planispiral (Pl. 2, figs $3,4)$. This is confirmed by study of all sectioned topotype specimens of these species (Banner, Gillmore et al., 1991). Contrary to the statement by Loeblich \& Tappan (1985, p.101), some transverse thin sections of topotype specimens of $A$. amiji show the presence of centrally-situated pillars, between the apertures of successive septa (Banner, Gillmore et al., 1991), whereas no such pillars are firmly known from transverse sections of Trochamijiella.

Although the primary type specimens of Haurania deserta Henson (e.g., Pl. 2, figs 5, 7, 8) do not show it, hypotypes (e.g. from Morocco, in Hottinger, 1967, Pl. 8, fig. 7) which undoubtedly belong to that genus possess very numerous radial partitions which bifurcate along the long axis of the test, producing at least two stacks of radial partitions in each chamber. Vertical bifurcation of the radial partitions is rare in both Amijiella and Trochamijiella. 
Classification. Following Loeblich \& Tappan (1985, 1988), both Amijiella and Haurania belong to the Loftusiacea (a superfamily of the suborder Textulariina), but the former genus may be referred to the Cyclamminidae Marie (subfamily Choffatellinae Maync) while the latter genus should be placed in the Spirocyclinidae Munier-Chalmas. Although this may correctly imply that the two genera have different palaeobiological close affinities, we cannot accept the conclusions. As noted above, both genera may have centrally-situated, although sparse, interseptal pillars, and Amijiella lacks the "continuous alveolar hypodermis" believed by Loeblich \& Tappan (1988, p.101) to characterise the Choffatellinae, or the "inner alveolar layer" considered by these authors (1988. p.98) to characterise the Cyclamminidae as a whole. Conversely, the Spirocyclinidae was said (Loeblich \& Tappan, 1988, p.106) to be "planispiral to irregularly planispiral, becoming peneropliform to cyclic" and this hardly characterises Haurania. Similarly, Trochamijiella has characteristics which agree with those of neither family, as they were defined by Loeblich \& Tappan (1988).

We consider that the genera Haurania, Amijiella and Trochamijiella may be easily confused; a classification which groups them together makes their differences more apparent. None of these genera has an alveolar hypodermis, yet each has a test which is dominantly uniserial; these characteristics should exclude them immediately from the Cyclamminidae and the Spirocyclinidae. They are all very similar to the genus Biokovina Gusic (Loeblich \& Tappan, 1988: p.91, Pl. 8, Figs 1-6), and differ principally in not being canaliculate. As has been pointed out elsewhere (Banner, Simmons \& Whittaker, 1991) canaliculation can develop only in the later parts of some tests of some genera of the Chrysalidinidae, but may characterise different genera in the Textulariidae. Therefore, even within one superfamily (e.g. the Textulariacea), morphocharacters such as canaliculi can have different importance in different subgroups. In this case, we consider that the presence or absence of canaliculation may characterise certain genera which otherwise are all essentially morphologically similar; they are all calc-agglutinating, with no alveolar hypodermis, become uncoiled and rectilinear in adult ontogeny, but have radial partitions inside their adult chambers and an areal (often cribrate) aperture. We would place them all in the Biokovinidae Gusic, 1977 (modifying the definition given by Loeblich \& Tappan, 1988, p.91). Incidentally, all of these four genera are of Jurassic age and could have had some palaeobiological affinity, even though it is probable that the immediate ancestors of each were distinct.

\section{Trochamijiella gollesstanehi sp. nov.}

(Pl. 1, figs 1-15)

1965 MS Iranica slingeri Gollesstaneh: 454-460, Pl. 175, figs 1-6; Pl. 176, figs 1-4; Pl. 177, figs 1-4; Pl. 178, figs 1-5; Pl. 179, figs 1-4; Pl. 180, figs 1-6; Pl. 181, figs 1-4; Pl. 182, figs 1-5; Pl. 183, figs 1-5. 1974 Iranica slingeri Gollesstaneh: 187 (Nomen mudum)

Derivation of name. For Ali Gollesstaneh, one-time Chief Palaeontologist, Exploration Division, O.S.C.O., Iran, who originally described and illustrated (MS) this species.

Diagnosis. A species of Trochamijiella in which the initial trochospire is succeeded by many uncoiled chambers developed in a rectilinear series which has initial breadth similar to the maximum diameter of the preceding coils but which slowly increases in breadth during ensuing growth (reaching double the initial breadth after about 15 successive rectilinear chambers have formed); the late rectilinear chambers are 7 to 8 times broader than high and possess about 10 or 12 radial partitions in their internal perimeters.

Holotype. BM(NH) P.52652, in thin section of Uweinat Formation limestone drilled subsurface in the Umm Shaif field, off-shore Abu Dhabi, U.A.E.

Material. Many hundreds of specimens in random thin section from the same stratigraphic levels and the same area of provenance as the holotype; also other specimens from Wadi Milaha and other areas of Oman. Paratypes deposited in the British Museum (Natural History) are in six limestone thin-sections registered as P. 52652-52657.

Description. The initial trochospire consists of about three whorls of low chambers, eight or nine in each whorl; the septa are curved and the septal apertures are initially interiomarginal and single but become areal and multiple in the last half of the last whorl. The uniserial, rectilinear part of the test has an initial breadth only slightly less than the maximum diameter of the last whorl of the initial coil, but the succeeding rectilinear chambers slowly increase in breadth and height. Their sutures are weakly or not at all depressed. The uniserial chambers are virtually circular in transverse section; they are five or six times as broad as high, and their height is only about $150 \%$ greater than the thickness of the septa which separate them. These septa have low overall convexity [the septa of the uniserial parts of the tests of Amijiella aniji (Pl. 2, figs 3,4) and Haurania desertn (Pl. 2, figs 5,8) are much more convex] but

\section{Explanation of Plate 1}

Figs 1-15. Trochamijiella gollesstanehi Athersuch, Banner \& Simmons, gen. nov. et sp. nov. all from the Uweinat Formation, Bathonian, subsurface, off-shore Abu Dhabi, U.A.E. Figs 1-7, 9-11, and 13-15 are of specimens from the Umm Shaif field, and are deposited in the British Museum (Natural History); the other specimen (Figs 8, 12) is from the Zakum field, also off-shore Abu Dhabi, and is deposited in the BP collection, Natural History Museum, London.

Fig. 1. Holotype, BMNH P.52652, $x 48$.

Figs 2-15. Paratypes. Fig. 2, P.52653, x75; Fig. 3, P.52656, x54; Fig. 4, P.52652, x24; Fig. 5, P.52652, x36; Fig. 6, P.52653, x53; Fig. 7, P.52652, x.33; Figs 8, 12, x32 and x64 respectively; Fig. 9, P.52652, x29; Fig. 10, P.52655, x.31; Fig. 11, P.52653, x24; Fig. 13, P.52654, x57; Fig. 14, P.52657, x45: Fig. 15, P.52652, x34. Figs 2, 5, 13 and 15 are transverse sections of the rectilinear part of the test, of varying obliquity to its long axis; the other figures are longitudinal sections. Fig. 1 shows the last whorl of the initial trochospire, in near-equatorial section, followed by the median part of the rectilinear chambers and finally by their more peripheral parts with the radial partitions. The off-centred axial section of the initial trochosphire is seen in Fig. 8 (enlarged in Fig. 12); a more off-centred, near-axial section is seen at the base of Fig. 10. Even when the initial spire cannot be seen in random section, the species is recognisable and is clearly distinct from other taxa (see Plate 2). 

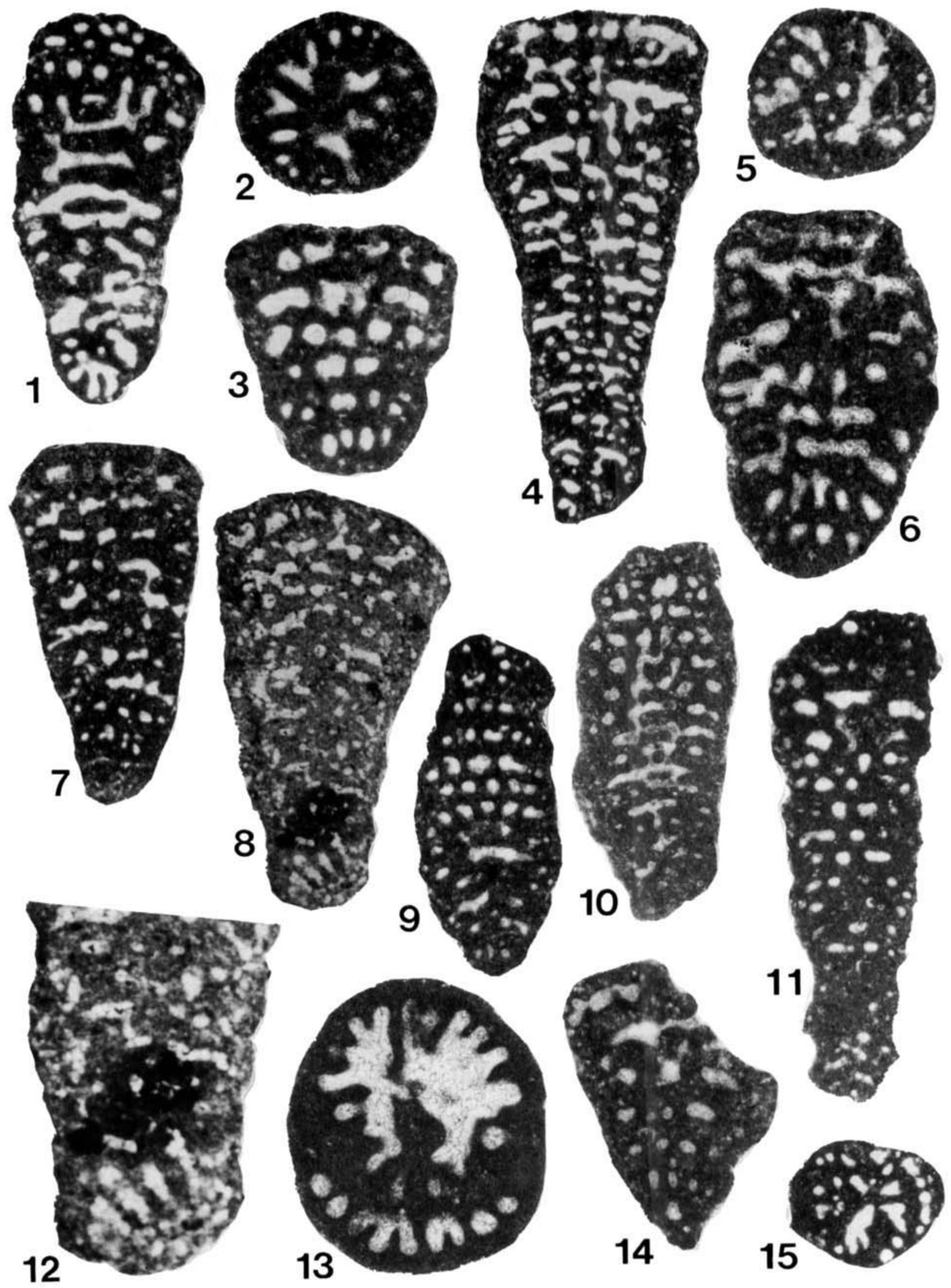
become corrugated where the radial partitions form (Text-fig. 2 and Pl. 1, figs 1,3, 4, 8, 12). There are about 20 radial partitions in the perimeters of each of the later chambers, and these partitions are of variable length (Pl. 1, figs 2, 5, 13), some reaching to the middle zone of each chamber but others remaining only at the perimeter; occasionally, these partitions bifurcate sporadically to develop incomplete double-stacks of partitions (Pl. 1, figs 1,10). The septal apertures of the rectilinear chambers are multiple and areal (Pl. 1, figs 1, 4, 5, 6, 8, 10), in the median zone of each septum.

Dimensions. Length of holotype (Pl. 1, fig. 1):1.4mm. Paratypes have greatest observed length of $2.8 \mathrm{~mm}$ (Pl. 1, fig. 4). Greatest observed breadth of uniserial chambers is $0.9 \mathrm{~mm}$ (Pl. 1, Fig. 13).

Locality and horizon of holotype and paratypes. Offshore Abu Dhabi, U.A.E., subsurface, in the middle and lower parts of the Uweinat Formation, Bathonian. The holotype and the paratypes which are deposited in the British Museum (Natural History) were all obtained from the Umm Shaif field.

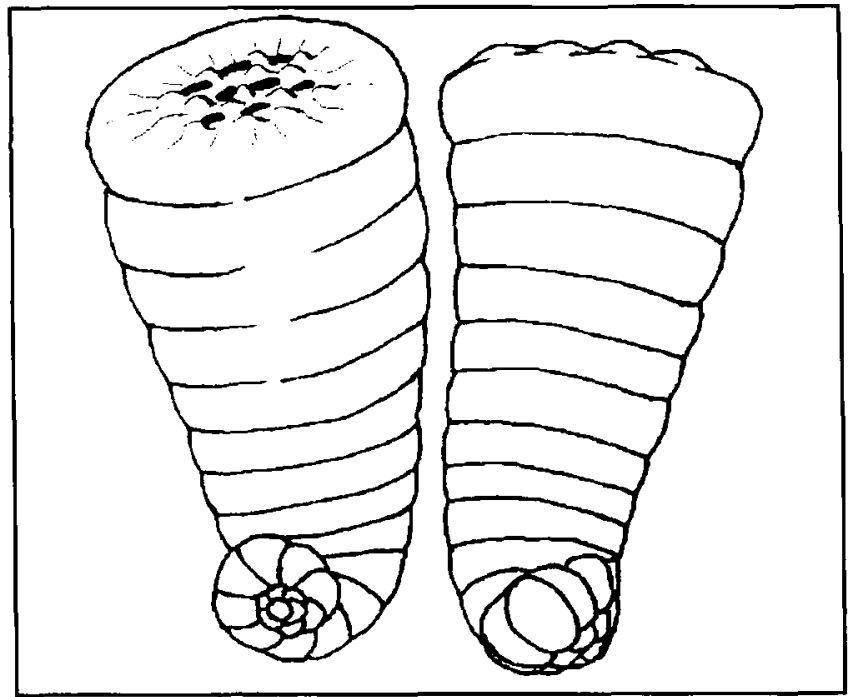

Fig. 1. Reconstruction of the supposed external appearance of Trochamijiella gollesstanehi, based on the random thin sections shown in Plate 1 and others in the BP collections, Natural History Museum, London.

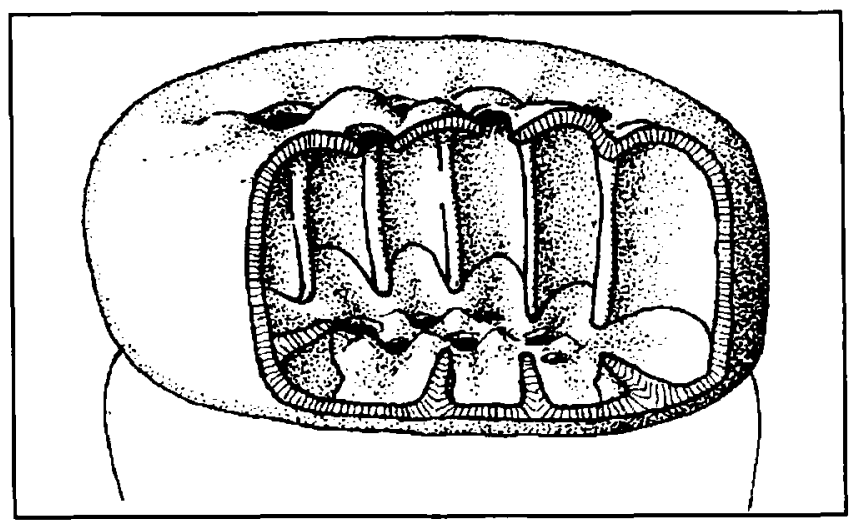

Fig.2. Diagram to show the supposed architecture of the last chamber of the rectilinear series in the test of Trochamijiella gollesstanehi; the chamber has been partly opened to show its internal structure.

\section{STRATIGRAPHY}

Trochamijiella gollesstanehi was first recorded by Gollesstaneh $(1965,1974)$, under the nomen nudum "Iranica slingeri", from the limestones of the Khami Group in Fars Province, southern Iran. He noted (1974, p.187) that it was an excellent marker for his "Zone VIII", the Pfendrina Zone, which he also found to contain P. trochoidea Smout \& Sugden, P. salernitana Sartoni \& Crescenti and other microfossils. He considered (1974, p.188) that the zone was probably Bathonian in its lower part and Callovian in its upper part.

"Iranica slingeri" was not mentioned by Kalantari (1986) in his review of the microfacies of Iranian limestones, but this author illustrated it (1986, p.113, Pl. 51.1) from the Surmeh Formation, Ahmadi anticline, of the Interior Fars area; it was dated as Bathonian, but misnamed. "Haurania amiji".

T. gollesstanehi has often been recorded by BP biostratigraphers (in unpublished internal reports) as occurring in the middle and lower parts of the Uweinat Member of the Araej Formation, limestones drilled subsurface in off-shore and on-shore Abu Dhabi, U.A.E. Here, T. gollesstanehi occurs with Pfenderina trochoiden and $P$. salernitana, and it has a similar microfossil association in equivalent strata of Oman.

The Uweinat Member was first defined from subsurface sections drilled in Qatar (Sugden \& Standring, 1975), where it is also a limestone with $P$. trochoidea. It is thought to have been deposited in the open, inner to middle regions of a carbonate shelf, and it is an important hydrocarbon reservoir in the

\section{Explanation of Plate 2}

Figs 1-4,6 Amijielln amiji (Henson), from the Muhaiwir Formation (Bajocian - early Bathonian), Government Water Well (570-573ft depth), Wadi Amij, Iraq. Fig. 1, holotype, BMNH P.35869, x80; this was drawn by Henson (1948, Pl. 15, fig. 9); Fig. 2, paratype, P.35864, x75, previously unfigured; Fig. 3, topotype (probably a paratype, sectioned after the original publication), P.52579, x145; un figured by Henson (1948) but figured by Hottinger (1967, Pl. 8, fig. 20); Fig. 4, paratype, P.35866, x140 (figured by Henson, 1948, Pl. 15, fig. 6).

Fig. 6, paratype, transverse section, P. 35870, x140 (Henson, 1948, PI. 15, fig. 10).

Figs 5, 7, 8, Haurania deserfa Henson, from the same locality and horizon as A. amiiji. All are paratypes. Fig. 5, BMNH P.35863, x55 (Henson, 1948 , Pl. 15, fig. 4); Fig. 7, P.35861, x70 (Henson, 1948, Pl. 15, fig. 2); Fig. 8, terminal part of specimen from slide P.35859, x120, unfigured by Henson (1948) but subsequently sectioned and figured at a smaller magnification by Hottinger (1967, Pl. 8, fig. 22). 

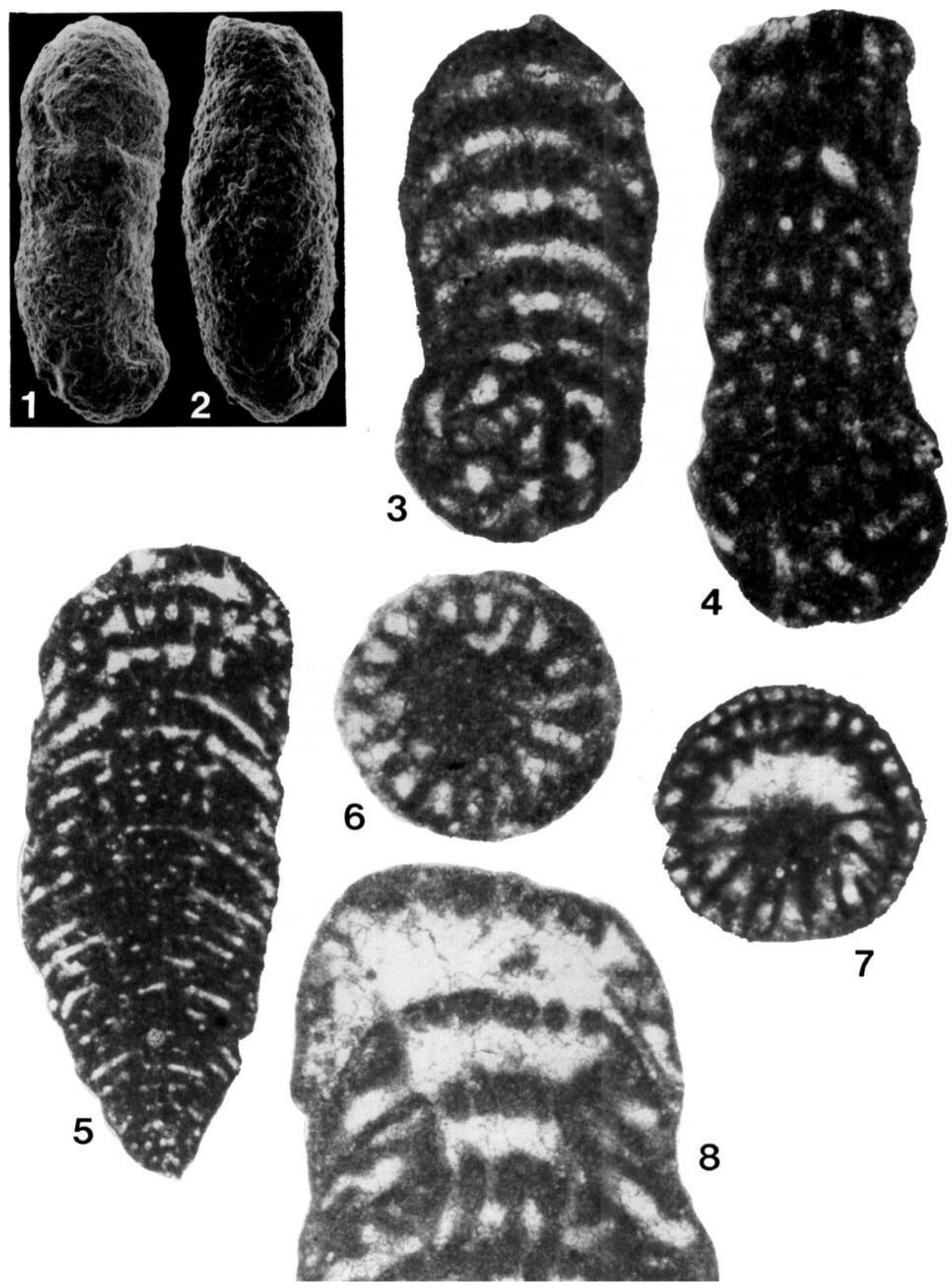

8 
Arabian Gulf region. Using sequence stratigraphy, lithostratigraphy and microfossils, the Uweinat Member has been correlated with the Atash Member of the Upper Dhruma Formation, Saudi Arabia (Powers, 1968), which has been shown by its macrofossils (principally ammonites) to be of Bathonian to Callovian age (Enay et al., 1987). It is most likely that the middle and lower parts of the Uweinat Member, in which $T$. gollesstanehi occurs, are of late Bathonian age at youngest. This agrees with the Bathonian dating of the occurrence of this species by Kalantari (1986, see above). Consequently, we consider that the stratigraphically highest occurrences of $T$. gollesstanehi mark the late Bathonian, and that the species is a useful zonal marker in the Middle East for rocks of this age.

On the other hand, Haurania deserta Henson and Amijiella amiji (Henson) (also referred to Haurania by Henson, 1948), in the U.A.E. - Oman area, occur in beds correlated with the Lower Araej Formation, stratigraphically below the Uweinat Member (and the youngest Trochamijiella gollesstanehi). The type specimens of both these species were obtained by Henson (1948) from the same depth in the Wadi Amij government water-well of western central Iraq, from beds originally thought to belong to the Mulussa limestone, a formation which is possibly as old as Triassic, in part at least. Consequently, Henson (1948) considered the types of these species to be of "Jurassic or Triassic age". Later (Dunnington et al., 1959, pp. 192-194) referred these same beds, and their microfossils, to the Bathonian Muhaiwir Formation, which has its type locality in Wadi Hauran, on the road to Qasr Amij, west Iraq, and is probably early. Bathonian at youngest (it may extend down into the Bajocian). The U.A.E. - Oman occurrences are probably also of this age. Kalantari (1986, pp. 112-113) has also retrieved $H$. deserta from the Bathonian Surmeh Formation of Iran. Both $H$. deserta and $A$. amiji have also been reported to occur in Italy in beds as young as the Bathonian (Sartorio \& Venturini, 1988, p.66) even although they also occur in older Jurassic limestones. We believe that the stratigraphically highest Haurania deserta and Amijiella amiji are useful zonal markers, in the marine, shelf carbonate rocks of the Middle East at least, for beds of early Bathonian age.

Consequently, we consider that Trochamijiella gollesstanehi and the Haurania deserta - Amijiella amiji association enable ready biostratigraphic recognition of two successive zones in Middle Eastern marine, shelf limestones, denoting the late Bathonian and the early Bathonian-Bajocian, respectively.

\section{ACKNOWLEDGEMENTS}

We wish to thank J.E. Whittaker, British Museum (Natural History), for taking the SEM photographs of Amijiella amiji, and G.K. Gillmore and P.V. York, also to the BM(NH), for the photomicrographs of the thin sections deposited in the Museum. This paper is published with permission kindly granted by BP Research and ADMA-OPCO, Abu Dhabi.

Manuscript received February 1991

Manuscript accepted October 1991 .

\section{REFERENCES}

Banner, F.T., Gillmore, G.K., Highton, J. \& Whittaker, J.E. 1991. Mesozoic Foraminifera from the Middle East at the Natural History Museum, London. British Museum (Natural History), London.

Banner, F.T., Simmons, M.D. \& Whittaker, J.E., 1991. The Mesozoic Chrysalidinidae (Foraminifera, Textulariacea) of the Middle East: The Redmond (Aramco) taxa and their relatives. Bull. Br. Mus. Nat. Hist. (Geol.), 47, 101-152.

Dunnington, H.V., Wetzel, R. \& Morton, D.M. 1959. Mesozoic and Palaeozoic. Lexique Stratigraphique International. Asie. 3, fasc. 10a. Iraq. 333pp. Centre National de la Recherche Scientifique, Paris.

Enay, R., Le Nindre, Y.M., Mangold, C., Manivit, J. \& Vaslet, D. 1987. Le Jurassique d'Arabie saodite centrale: nouvelles donnees sur la lithostratigraphie, les paléoenvironnements, les faunes d'Ammonites, les âges et les correlations. Geobios, Mém. Spec. 9, 13-66, Lyon.

Gollesstaneh, A. 1965 MS. A micropalaeontological study of the Upper Jurassic and Lower Cretaceous of Southern Iran. University of London, Unpublished Ph.D. Thesis .

Gollesstaneh, A. 1974. Biostratigraphie du "Khami-group" et limite Jurassique-Crétacé de la province du Fars (Iran méridionale). The biostratigraphy of the "Khami-group" and the Jurassic-Cretaceous boundary in Fars province (southern Iran). Bulletin du Bureau de Recherches Géologique et Miniéres (B.R.G.M.), sér. 2, section IV, No.3, 165-197.

Henson, F.R.S. 1948. Larger Imperforate Foraminifera of South-Western Asia. Families Lituolidae, Orbitolinidae and Meandropsinidae. 127pp., 16pls. British Museum (Natural History), London.

Hottinger, L. 1967. Foraminifères imperforés du Mésozoique marocain. Notes et Mémoires du Service géologique du Maroc, 209, 1-168, 20 pls.

Kalantari, A. 1986. Microfacies of carbonate rocks of Iran. National Iranian Oil Company, Geological Laboratories Publication 11, 1-287, Pls 1-135. Tehran.

Loeblich, A.R. Jr. \& Tappan, H. 1985. Some new and redefined genera and families of agglutinated foraminifera. I. Journal of Foraminiferal Research, 15, 91-104, Pls. 1-3.

Loeblich, A.R. Jr. \& Tappan, H. 1988. Foraminiferal genera and their classification. 1, 970pp., 2, 212pp. 847 Pls. Van Nostrand Reinhold, New York.

Powers, R.W. 1968. Lexique Stratigraphique International. Asie. 3, fasc. 10b 1. Saudi Arabia (excluding Arabian Shield). 177pp. Centre National de la Recherche Scientifique, Paris.

Sartorio, D. \& Venturini, S. 1988. Southern Tethys Biofacies. 234pp., Agip S.p.A., S. Donato Milanese, Milan.

Sugden, W.\&Standring, A.J. 1975. Lexique Stratigraphique International Asie. 3, fasc. 10b 3. Qatar Peninsula. 120pp. Centre National de la Recherche Scientifique, Paris. 